\title{
Nature and Origin of the Amphibolites in the Precambrian Basement Complex of Iseyin and Ilesha Schist Belts, Southwestern Nigeria
}

\author{
Anthony Temidayo Bolarinwa ${ }^{1} \&$ Morenike Abimbola Adeleye ${ }^{1}$ \\ ${ }^{1}$ Department of Geology, University of Ibadan, Ibadan, Nigeria \\ Correspondence:Anthony Temidayo Bolarinwa, Department of Geology, University of Ibadan, Ibadan, Nigeria \\ E-mail: atbola@yahoo.com
}

Received: February 9, 2015

Accepted: March 3, 2015

Online Published: April 19, 2015

Doi: $10.5539 /$ jgg.v7n2p6

URL: http://dx.doi.org/10.5539/jgg.v7n2p6

\begin{abstract}
Petrographic and geochemical studies of amphibolites from Wonu-Apomu area in Iseyin-Oyan schist belt and Ife-Ilesa area in Ilesha schist belt, southwestern Nigeria, were carried out with a view to unravel their nature and petrogenesis. The amphibolites in Wonu-Apomu are associated with quartzite, quartz schist, talc-schist, granite and pegmatites, while those of Ife-Ilesha area are associated with anthophyllite schist, talc tremolite and talc chlorite schists.

Chemical data of the amphibolites showed high $\mathrm{Al}_{2} \mathrm{O}_{3}(>14 \%), \mathrm{Fe}_{2} \mathrm{O}_{3}(>12.40 \%), \mathrm{CaO}(>8.10), \mathrm{Na}_{2} \mathrm{O}(>3.10 \%)$ and $\mathrm{K}_{2} \mathrm{O}(>5.0 \%)$ contents. Trace element data showed that the amphibolites are enriched in $\mathrm{Ba}(>137 \mathrm{ppm}), \mathrm{Sr}$ $(>122 \mathrm{ppm}), \mathrm{Rb}(>33 \mathrm{ppm}), \mathrm{Zr}(55 \mathrm{pm})$ and $\mathrm{Y}(>37 \mathrm{ppm})$, but impoverished in $\mathrm{Cr}(<62 \mathrm{ppm}), \mathrm{Ni}(<57 \mathrm{ppm})$ and $\mathrm{Zn}$ $(<83 \mathrm{ppm})$. Petrogenetic indices and discriminant plots of $\mathrm{Na}_{2} \mathrm{O}+\mathrm{K}_{2} \mathrm{O}$ vs $\mathrm{SiO}_{2}, \mathrm{Ga}$ vs $\mathrm{Y}, \mathrm{Zr} / \mathrm{Y}$ vs Zr, Cr vs Ni, $\mathrm{Fe}_{2} \mathrm{O}_{3}-\mathrm{Na}_{2} \mathrm{O}+\mathrm{K}_{2} \mathrm{O}-\mathrm{MgO}$, indicated tholeiitic basalt affinity of the amphibolites and emplacements of the precursor basaltic rocks within continental crust.
\end{abstract}

Keywords:amphibolites, petrogenesis, tholeiites, Iseyin schist belt, Ilesa schist belt

\section{Introduction}

A number of investigations have been carried out by various workers on the amphibolites within the schist belts of the Nigerian basement complex. The Proterozoic Ilesa schist belt of southwestern Nigeria has been mapped in various degrees of details by workers, such as, Deswardt (1953), Hubbard (1966, 1975), Elueze (1980), Klemm et al., (1984) and Kehinde-Phillips (1991). This was largely due to the discovery of gold in the Ilesa area in 1940, as the Ilesa amphibolites Complex was suspected to be the source of the alluvial gold.

On the basis of field relationships and petrological features, the rocks of Wonu-Apomu area have been recognized to comprise the quartzite and quartz schist, amphibolites and related rocks, Older granite and pegmatites, talc and talc schist (Ige, 1985); while the rock of Ilesa area have been grouped into gneiss-migmatite complex, mafic-ultramafic suite (or amphibolites complex), metasedimentary assemblages and intrusive suite of granitic rocks (Elueze, 1980).

Elueze (1986) has indicated that the rocks of the Ilesa schist belt are structurally divided into two main segments by a major fracture zone, often referred to as the Iwaraja fault. Olade and Elueze (1979) has also identified and described four textural varieties of the Ilesa amphibolites; which are massive, banded, schistose and strongly gneissic textural types. Moreover, Elueze (1982) identified various ore minerals in the Ilesa amphibolites and described their metallographic features. Based on geochemical characteristics, Elueze (1980) and Olade and Elueze (1979) have suggested a tholeiitic basalt precursor and emplacement within the continental crust for the Ilesa amphibolites, although Ajayi (1980) proposed a dual parentage for these amphibolites.

Most of these investigations on the amphibolites occurrences within the Precambrian basement complex of southwestern Nigeria tend to emphasize their field relations, petrological descriptions, mineralogical attributes and chemical compositions. Various efforts to unravel the petrogenetic affinity have been dogged with controversy. Therefore, this present investigation largely seeks to generate chemical data to unravel the nature and origin of the amphibolites around Wonu-Apomu in the Iseyin-Oyan schist belt and those of Ilesa in the Ife-Ilesa schist belt, southwestern Nigeria. 


\section{Location and Geographical Features of the Study Areas}

The areas of investigation lie within the Precambrian Basement Complex of southwestern Nigeria (Figure1). The main study area around Wonu-Apomu include towns and villages like Wonu, Apomu, Pagbo, Gbangba, Adigun, Laduntan, Ojewumi, Adetonwa and Elepo (Figure 2); while the area around Ilesa include Ita Osan, Aba Risawe, Isaobi, Ileki, Imosan and Agbao (Figure 3). The area around Wonu-Apomu is delineated by latitude $7^{\circ} 15^{\prime}$ and $7^{\circ}$ $19^{\prime} \mathrm{N}$ and longitude $4^{\circ} 3^{\prime}$ and $4^{\circ} 6^{\prime} \mathrm{E}$; while the Ilesa area is defined by latitude $7^{\circ} 31^{\prime}$ and $7^{\circ} 38^{\prime} \mathrm{N}$ and longitude $4^{\circ} 38^{\prime}$ and $4^{\circ} 45^{\prime} \mathrm{E}$.

The study areas are characterized by rugged topography with elevations ranging from about $800 \mathrm{~m}$ to about $1200 \mathrm{~m}$. The relatively lowland areas are underlain by quartz schist and pegmatites while the higher areas are underlain by amphibolite and anthophyllite-talc schist. The lowland areas are transected by streams and rivers.

\section{Geology and Petrography}

The Wonu-Apomu and Ilesa areas lie within the NE-SW trending schist belts of the basement complex of southwestern Nigeria. The two areas are characterized by granitic gneiss, low to medium grade metasedimentary and metavolcanics rocks, notably quartzite and quartz schists, amphibolites and talc schist. Others are porphyritic granite and pegmatites (Figures 2 and 3). The gneisses are finely foliated and contained quartz, plagioclase feldspar, microcline, biotite and hornblende (Adeleye, 2009). Quartzite commonly grade into quartz schist with increasing mica content. The massive amphibolites are predominant in the Wonu-Apomu area though they are deeply weathered in most parts (Adeleye, 2009). Essential minerals in the massive amphibolites include hornblende, plagioclase feldspar, quartz, chlorite, biotite, pyroxene, anthophyllite and opaque minerals.

In Ilesa area, N-S trending lenticular, massive, banded, schistose or strongly foliated amphibolites and amphibole schist varieties occur within an essentially gneissic terrain (Adeleye, 2009). The dominant minerals in the amphibolites are hornblende and plagioclase. Other subordinate minerals are quartz, chlorite, biotite, pyroxene anthophyllite and opaque that is generally less the $5 \%$ of the modal composition (Adeleye, 2009). The gneissic varieties contain plagioclase and hornblende bands. Some samples contain sphene, epidote, apatite and ore minerals, notably chalcopyrite, pyrrhotite, pentlandite and magnetite. Pyroxenes are present in some while epidote and microcline are well developed in the felsic variety (Olade \& Elueze, 1979; Ajayi, 1980). The amphibolites in Ilesa area vary in texture, mineralogy and mode of occurrence. They may be massive, like the type predominating in Wonu-Apomu area or banded with foliation defined by felsic and amphibole rich bands. Essential mineral constituents are hornblende, quartz and plagioclase. Accessory minerals include epidote, garnet, titanite, rutile and ilmenite (Adeleye, 2009).

Rocks of the Older granite series are exposed mostly as low whale backs and pavements in both areas. Microcline constitutes over $30 \%$ of the modal composition with other principal minerals like quartz, plagioclase feldspar and mica. Pegmatite veins are intruded into the amphibolites and amphibole schists (Adeleye, 2009).

\section{Materials and Methods}

Twenty samples of amphibolites were collected from outcrops in Wonu-Apomu and Ilesa areas. The samples were selected for thin sectioning and chemical analysis. Thin section of the amphibolite samples were prepared and examined under the transmitted light of petrological microscope in the Department of Geology, University of Ibadan, Ibadan, Nigeria. Duplicate amphibolite samples were pulverized into fine powder of about 20 mesh size and analysed at the Activation Laboratory in Ontario, Canada. The Inductively Coupled Plasma (ICP) was used to determine the major oxides while Inductively Coupled Plasma-Mass Spectrometry (ICP-MS) was used for the simultaneous multi-element determination of the trace and rare earth elements after total digestion. Pressed powdered pellets were prepared from $3-5 \mathrm{~g}$ of the samples. This was digested with a mixture of $0.2 \mathrm{~g}$ aliquot and $1.5 \mathrm{~g} \mathrm{LiBO}_{2} / \mathrm{LiB}_{4} \mathrm{O}_{7}$ flux in graphite crucible. The crucibles were heated at $980^{\circ} \mathrm{C}$ for 30 minutes in an oven. The bead formed was cooled and dissolved in $5 \% \mathrm{HNO}_{3}$ (ACS grade nitric acid diluted in demineralised water) Calibration standards and blank solutions were used in the sequence of analyses to determine the precision which was less than 5\%. The major elements determined are $\mathrm{SiO}_{2}, \mathrm{Al}_{2} \mathrm{O}_{3}, \mathrm{Fe}_{2} \mathrm{O}_{3(\mathrm{t})}, \mathrm{MnO}$, $\mathrm{CaO}, \mathrm{Na}_{2} \mathrm{O}, \mathrm{K}_{2} \mathrm{O}, \mathrm{TiO}_{2}$, and $\mathrm{P}_{2} \mathrm{O}_{5}$, while the trace elements include $\mathrm{Be}, \mathrm{Ba}, \mathrm{Sr}, \mathrm{Y}, \mathrm{Zr}, \mathrm{Zn}, \mathrm{Cs}, \mathrm{Rb}, \mathrm{Nb}, \mathrm{Sn}, \mathrm{Co}, \mathrm{Cu}$, $\mathrm{V}, \mathrm{Ga}, \mathrm{Cr}, \mathrm{La}, \mathrm{Ce}, \mathrm{Hf}, \mathrm{Ta}, \mathrm{Nd}$, Th and U. Loss on ignition (LOI) was determined by measuring the weight loss after heating a $1 \mathrm{~g}$ split sample at $95^{\circ} \mathrm{C}$ for 90 minutes. 


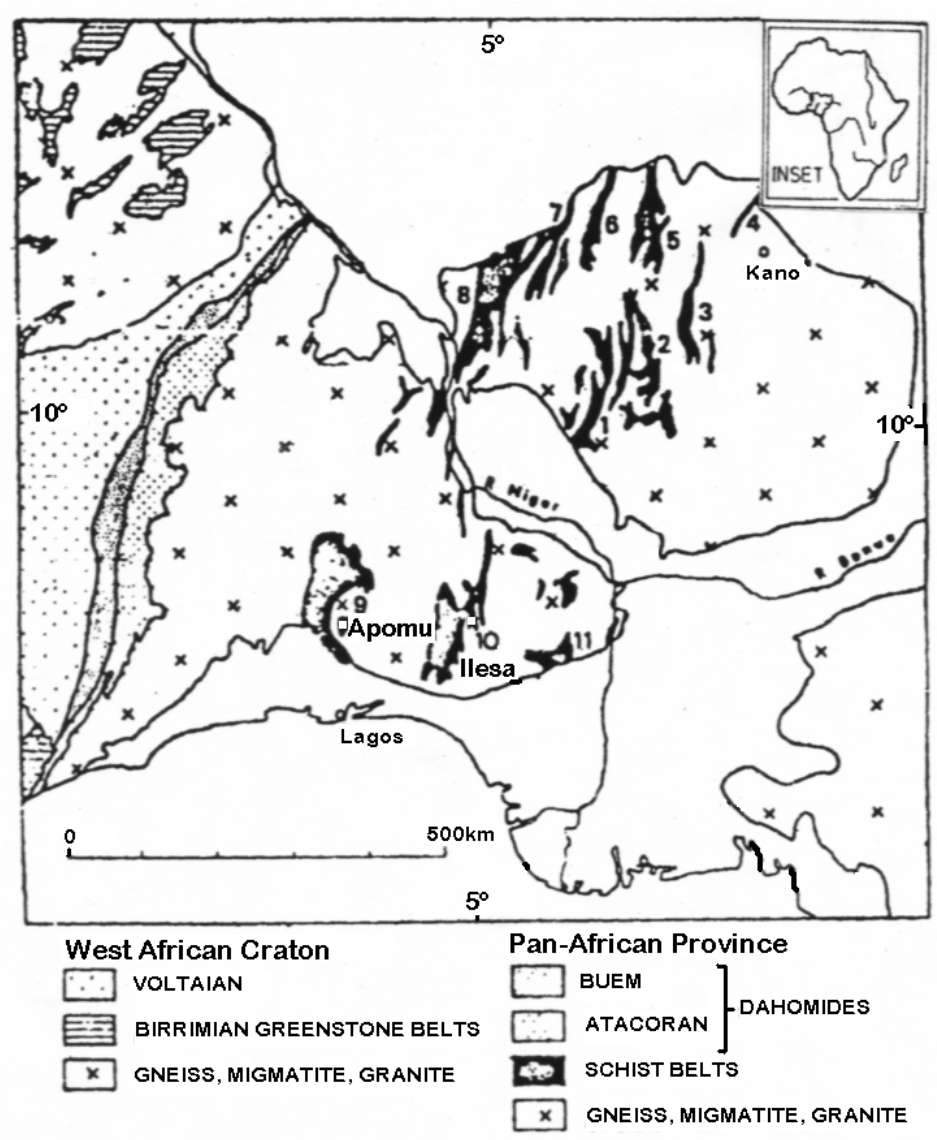

Figure 1. Location of Apomu (9-Iseyin schist belt) and Ilesa (10-Ilesa schist belt) within the Nigerian sector of the Pan-African Province of West Africa (Modified after Turner, 1989)

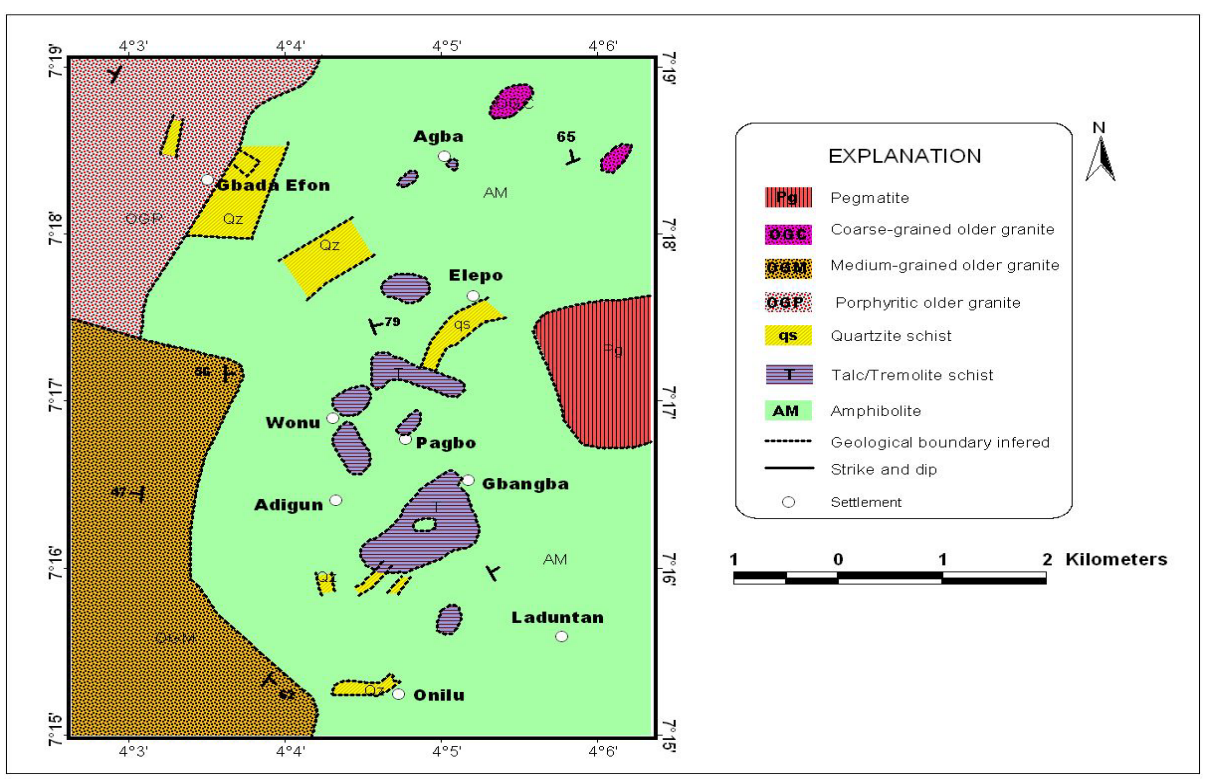

Figure 2. Geological map of Wonu-Apomu area (modified after Akin-Ojo, 1992) 


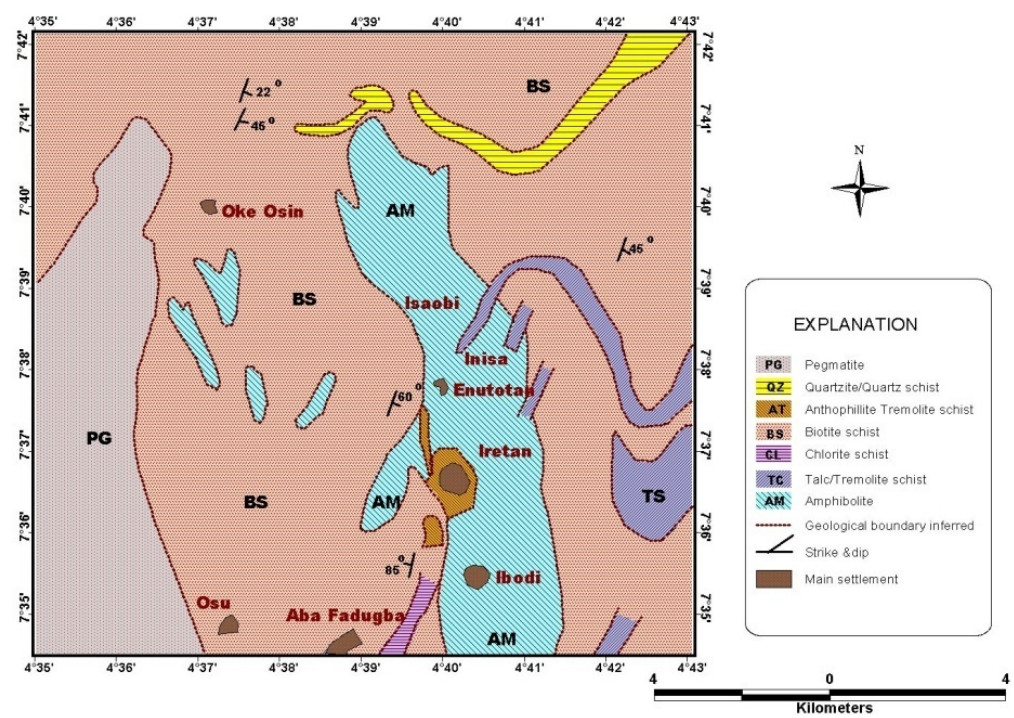

Figure 3. Geological map of Ilesa area (modified after Kehinde-Phillips, 1991)

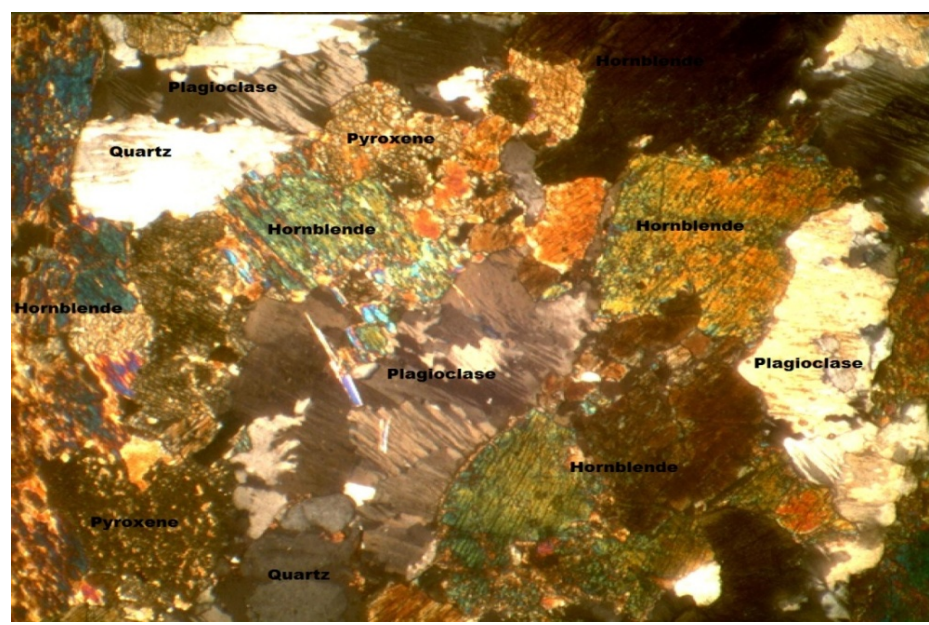

Figure 4. Photomicrograph of massive amphibolite of Wonu-Apomu area showing plagioclase, hornblende, pyroxene and quartz

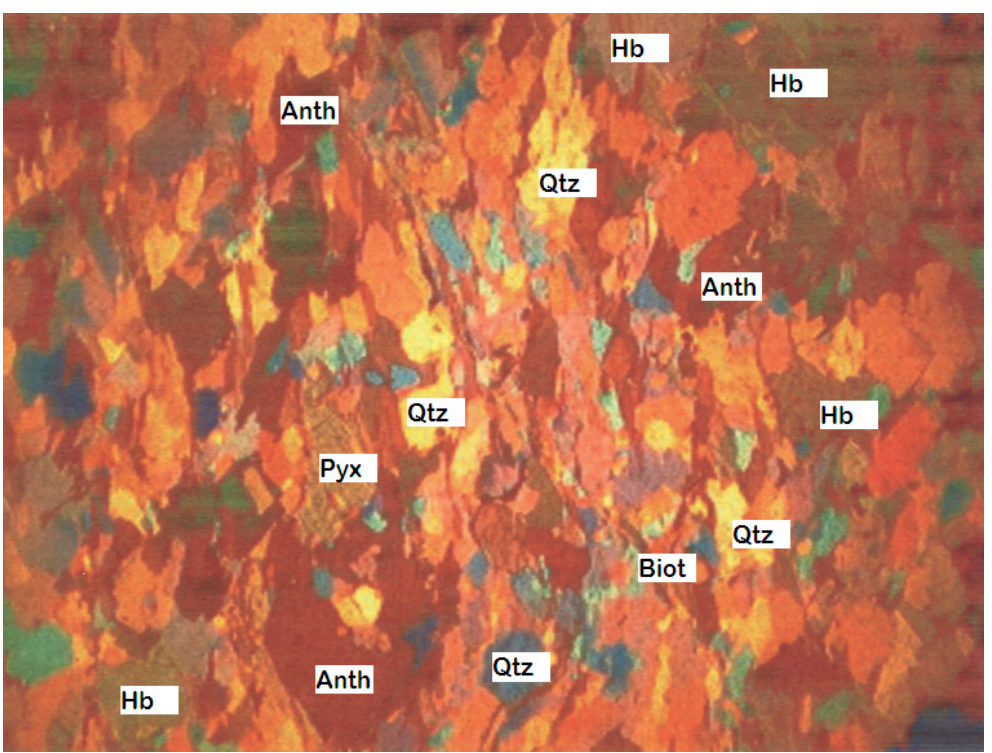

Figure 5. Photomicrograph of foliated and sheared amphibolite of Ilesa area showing hornblende (Hb), pyroxene (Pyx), chlorite (the green specs), anthophyllite (Anth), quartz (Qtz) and biotite (Biot) 


\section{Results and discussion}

Outcrops of the amphibolites occur as smooth small ovoid lenses. They are dark grey to black, aphanitic to microporphyritic in texture. Petrographic study of the amphibolites (Figures 4 and 5) showed the dominance of hornblende (64-71\%), plagioclase feldspar (10-12\%), anthophyllite (3-6\%) and chlorite (3-5\%). Other minerals present are biotite, quartz, clinopyroxene (augite) and orthopyroxene (hypersthene) and opaque minerals, which are generally less than $5 \%$ each (Table 1). Green hornblende, chlorite and epidote are some of the alteration minerals in the samples. The light brown augite is clearly distinguishable from the amphiboles by its characteristic cleavage of $87^{\circ} / 93^{\circ}$. The brown amphiboles are classified as calcic amphiboles, notably hornblende (Adeleye, 2009). Plagioclase is the calcium rich types with bold multiple twining characteristic of andesine to labradorite composition as observed under the transmitted microscope. Anthophyllite appear 'sack-like,' light brown and yielded straight extinction.

Major and trace element compositions of the amphibolites are presented in Table 2 while the average concentrations as compared with other amphibolites elsewhere are given in Table 3. As shown in Table 2, the amphibolites of Wonu-Apomu have silica concentrations ranging from 44.78-50.62 wt \% while Ilesha amphibolites ranged 44.86-49.10 wt\% and average composition of 48.91 and $47.27 \%$ for Wonu Apomu and Ilesa amphibolites, respectively. This indicated that the $\mathrm{SiO}_{2}$ contents are not markedly varied within samples, showing typical mafic silica composition. The alumina contents vary slightly, with higher values for samples from Ilesa (17.29 wt\%) compared to the Wonu-Apomu samples (15.11 wt \%). These values compare favourably well with amphibolites elsewhere in Nigeria (Elueze, 1985; Elueze and Okunlola, 2003; Okunlola et al, 2007) (Table 3). There are, however, significant variations in $\mathrm{MgO}, \mathrm{TiO}_{2}, \mathrm{MnO}$ and $\mathrm{P}_{2} \mathrm{O}_{5}$ contents of the amphibolites. Wonu-Apomu samples have $\mathrm{MgO}$ concentrations ranging from $8.08-12.5 \%$, while Ilesa samples contained $7.85-11.10 \%$. Similarly, $\mathrm{TiO}_{2}, \mathrm{MnO}$ and $\mathrm{P}_{2} \mathrm{O}_{5}$ contents were $0.25-0.88 \%, 0.07-0.23 \%$ and $0.01-0.05 \%$ for the Wonu-Apomu samples, while Ilesa samples have $0.39-0.86 \%, 0.08-0.14 \%$ and $0.02-0.05 \%$ for the $\mathrm{TiO}_{2}, \mathrm{MnO}$ and $\mathrm{P}_{2} \mathrm{O}_{5}$ respectively (Table 3).

Table 1. Average modal composition of amphibolites in Wonu-Apomu and Ilesa areas

\begin{tabular}{lllllllllll}
\hline Minerals & 1 & 2 & 3 & 4 & 5 & 6 & 7 & 8 & 9 & 10 \\
\hline Hornblende & 64 & 69 & 66 & 71 & 70 & 69 & 67 & 67 & 66 & 68 \\
Plagioclase & 12 & 11 & 11 & 11 & 12 & 12 & 11 & 12 & 10 & 12 \\
Biotite & 4 & 4 & 4 & 4 & 4 & 2 & 4 & 3 & 4 & 4 \\
Quartz & 4 & 3 & 4 & 3 & 3 & 4 & 4 & 4 & 4 & 4 \\
Chlorite & 5 & 5 & 5 & 3 & 3 & 3 & 3 & 4 & 4 & 3 \\
Anthophyllite & 5 & 3 & 4 & 4 & 4 & 5 & 6 & 5 & 6 & 4 \\
Pyroxene & 4 & 4 & 4 & 2 & 2 & 3 & 3 & 3 & 4 & 4 \\
Opaque & 2 & 1 & 2 & 2 & 2 & 2 & 2 & 2 & 2 & 1 \\
\hline Total & 100 & 100 & 100 & 100 & 100 & 100 & 100 & 100 & 100 & 100 \\
1 - 5:Wonu-Apomu samples & & & & & & & & & & \\
6-10:Ilesa samples & & & & & & & & & &
\end{tabular}

Table 2. Major (wt $\%)$ and trace element ( $\mathrm{ppm})$ composition of amphibolites of Wonu-Apomu and Ilesa areas

\begin{tabular}{lllllllllll}
\hline & 1 & 2 & 3 & 4 & 5 & 6 & 7 & 8 & 9 & 10 \\
\hline $\mathrm{SiO}_{2}$ & 50.60 & 50.03 & 50.62 & 48.50 & 44.78 & 46.38 & 48.72 & 44.86 & 47.29 & 49.10 \\
$\mathrm{Al}_{2} \mathrm{O}_{3}$ & 15.05 & 14.81 & 15.26 & 16.41 & 14.01 & 16.55 & 15.80 & 15.20 & 18.67 & 20.22 \\
$\mathrm{Fe}_{2} \mathrm{O}_{3(t)}$ & 12.52 & 14.10 & 13.03 & 12.27 & 14.62 & 12.67 & 12.15 & 13.34 & 12.48 & 11.56 \\
$\mathrm{MnO}$ & 0.09 & 0.12 & 0.15 & 0.07 & 0.23 & 0.11 & 0.09 & 0.12 & 0.14 & 0.08 \\
$\mathrm{MgO}$ & 9.65 & 8.11 & 8.08 & 11.20 & 12.15 & 10.18 & 9.44 & 11.16 & 8.96 & 7.85 \\
$\mathrm{CaO}$ & 8.72 & 9.45 & 9.22 & 9.25 & 10.00 & 9.23 & 10.28 & 10.55 & 9.32 & 8.11 \\
$\mathrm{Na} \mathrm{O}_{2} \mathrm{O}$ & 1.25 & 1.78 & 1.56 & 1.13 & 1.88 & 2.05 & 1.96 & 2.72 & 1.28 & 1.34 \\
$\mathrm{~K}_{2} \mathrm{O}$ & 0.99 & 0.82 & 0.75 & 0.46 & 0.65 & 0.64 & 0.55 & 0.81 & 0.81 & 0.85 \\
$\mathrm{TiO}_{2}$ & 0.46 & 0.25 & 0.51 & 0.32 & 0.88 & 0.76 & 0.61 & 0.85 & 0.46 & 0.39 \\
$\mathrm{P}_{2} \mathrm{O}_{5}$ & 0.02 & 0.05 & 0.01 & 0.03 & 0.02 & 0.03 & 0.02 & 0.05 & 0.02 & 0.03 \\
$\mathrm{LOI}$ & 0.35 & 0.32 & 0.25 & 0.34 & 0.28 & 0.26 & 0.33 & 0.24 & 0.35 & 0.28 \\
\hline Total & 99.70 & 99.84 & 99.44 & 99.98 & 99.50 & 99.86 & 99.95 & 99.90 & 99.78 & 99.81 \\
\hline & & & & & & & & & &
\end{tabular}




\begin{tabular}{|c|c|c|c|c|c|c|c|c|c|c|}
\hline $\mathrm{Ba}$ & 350 & 99 & 86 & 250 & 135 & 231 & 88 & 96 & 126 & 144 \\
\hline Co & 85 & 76 & 68 & 85 & 40 & 56 & 48 & 82 & 69 & 53 \\
\hline $\mathrm{Cr}$ & 92 & 58 & 65 & 92 & 88 & 78 & 65 & 94 & 45 & 51 \\
\hline $\mathrm{Cu}$ & 40 & 35 & 48 & 51 & 66 & 25 & 72 & 98 & 66 & 45 \\
\hline $\mathrm{Ga}$ & 25 & 28 & 26 & 27 & 29 & 32 & 46 & 38 & 23 & 66 \\
\hline $\mathrm{Ni}$ & 46 & 68 & 24 & 85 & 98 & 74 & 25 & 85 & 46 & 23 \\
\hline $\mathrm{Rb}$ & 38 & 26 & 32 & 29 & 40 & 27 & 36 & 32 & 28 & 46 \\
\hline $\mathrm{Sr}$ & 125 & 132 & 143 & 106 & 110 & 145 & 124 & 106 & 116 & 120 \\
\hline V & 53 & 56 & 72 & 94 & 68 & 77 & 92 & 98 & 56 & 62 \\
\hline $\mathrm{Y}$ & 38 & 44 & 26 & 32 & 45 & 45 & 32 & 39 & 42 & 25 \\
\hline $\mathrm{Zr}$ & 62 & 48 & 57 & 49 & 59 & 64 & 46 & 56 & 48 & 66 \\
\hline $\mathrm{Zn}$ & 98 & 120 & 96 & 96 & 80 & 90 & 82 & 94 & 85 & 62 \\
\hline $\mathrm{K} / \mathrm{Rb}$ & 216.2 & 261.7 & 194.5 & 131.6 & 134.9 & 194.7 & 126.8 & 210.0 & 241.8 & 153.3 \\
\hline $\mathrm{Rb} / \mathrm{Sr}$ & 0.304 & 0.197 & 0.224 & 0.274 & 0.364 & 0.186 & 0.290 & 0.301 & 0.241 & 0.383 \\
\hline $\mathrm{K} / \mathrm{Ba}$ & 23.5 & 68.7 & 72.4 & 15.30 & 40.01 & 22.99 & 51.86 & 70.01 & 53.74 & 48.98 \\
\hline $\mathrm{Ga} / \mathrm{Y}$ & 0.658 & 0.636 & 1.00 & 0.843 & 0.644 & 0.711 & 1.438 & 0.974 & 0.548 & 1.56 \\
\hline $\mathrm{Rb} / \mathrm{Y}$ & 1.00 & 0.590 & 1.231 & 0.906 & 0.888 & 0.6 & 1.125 & 0.820 & 0.667 & 1.84 \\
\hline $\mathrm{Na} / \mathrm{K}$ & 1.129 & 1.941 & 1.860 & 2.196 & 2.586 & 2.864 & 3.186 & 0.300 & 1.413 & 1.409 \\
\hline $\mathrm{Ba} / \mathrm{Rb}$ & 9.21 & 3.808 & 2.688 & 8.62 & 3.375 & 8.55 & 2.44 & 3.00 & 4.50 & 3.130 \\
\hline $\mathrm{Ni} / \mathrm{Co}$ & 0.541 & 0.885 & 0.353 & 1.00 & 2.45 & 1.32 & 0.521 & 1.037 & 0.667 & 1.00 \\
\hline $\mathrm{CaO} / \mathrm{Al}_{2} \mathrm{O}_{3}$ & 0.579 & 0.638 & 0.604 & 0.564 & 0.714 & 0.558 & 0.651 & 0.694 & 0.499 & 0.40 \\
\hline
\end{tabular}

1 - 5:Wonu-Apomu samples

6 - 10:Ilesa samples

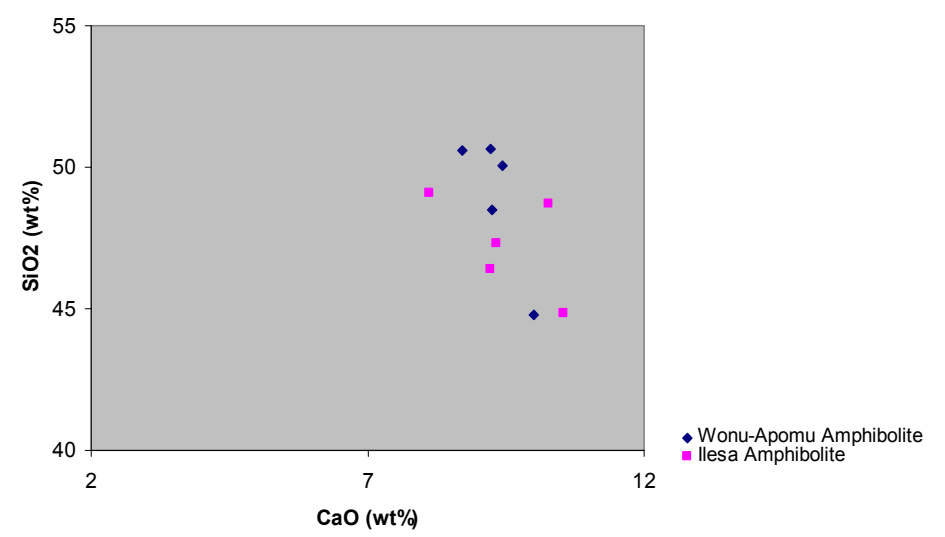

Figure 6. Plot of $\mathrm{SiO}_{2}$ vs $\mathrm{CaO}$ for Wonu-Apomu and Ilesa amphibolites (Brown et al., 1979)

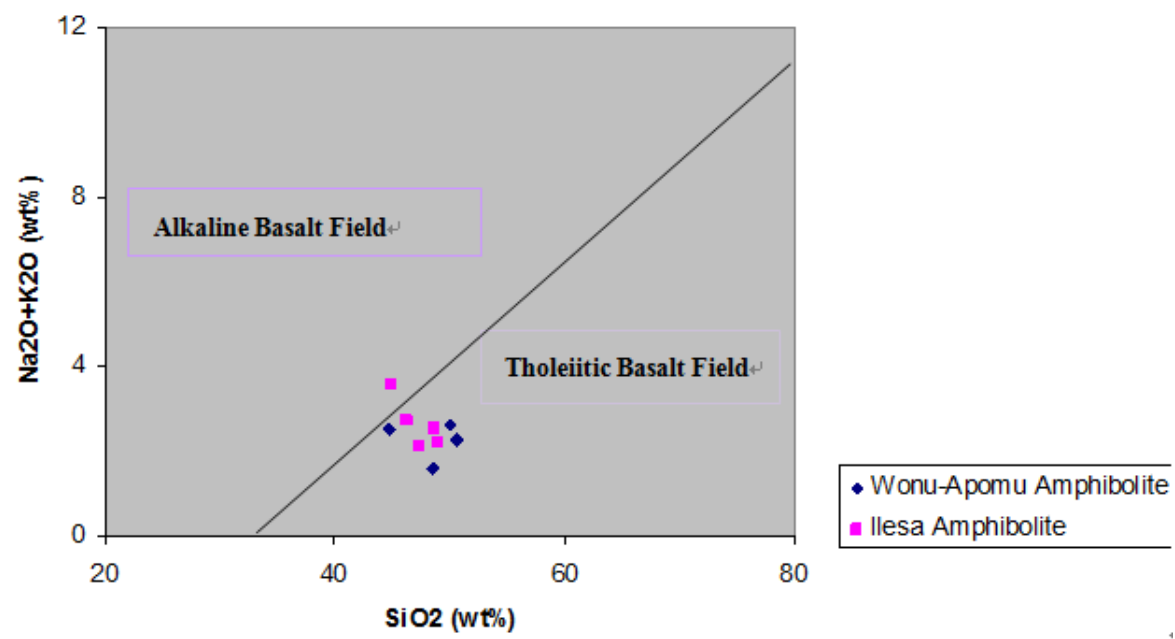

Figure 7. Plot of $\mathrm{Na}_{2} \mathrm{O}+\mathrm{K}_{2} \mathrm{O}$ vs $\mathrm{SiO}_{2}$ for Wonu-Apomu and Ilesa amphibolites (Irvine and Baragar, 1971) 


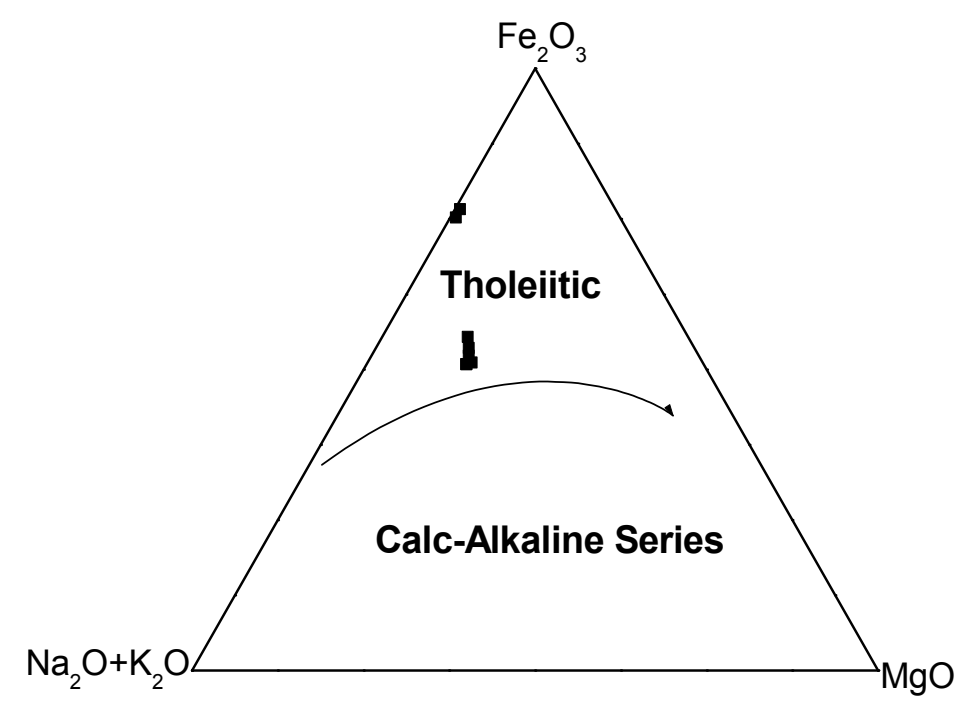

Figure $8 . \mathrm{Fe}_{2} \mathrm{O}_{3}-\mathrm{Na}_{2} \mathrm{O}+\mathrm{K}_{2} \mathrm{O}-\mathrm{MgO}$ ternary plot for Wonu-Apomu and Ilesa amphibolites

The $\mathrm{Fe}_{2} \mathrm{O}_{3(t)}$ contents are high for both amphibolites of Wonu-Apomu (13.31\%) and Ilesa (12.44\%) areas. The $\mathrm{CaO}$ concentrations 8.72-10.55\% for Wonu Apomu and Ilesa samples reflected the high Ca-plagioclase contents observed in the amphibolites. The high magnesia $(>9.5 \%)$ and lime contents of the amphibolites reflected the basic nature of the amphibolites. $\mathrm{MgO}$ and $\mathrm{Fe}_{2} \mathrm{O}_{3(t)}$ contents of the Wonu Apomu and Ilesa amphibolites are enhanced relative to other amphibolites elsewhere in Nigeria (Table 3). On the whole, major element composition of the Wonu Apomu and Ilesa areas are quite similar. However, the amphibolite samples do not compare favourably with other amphibolites elsewhere in Nigeria (Table 3). The differences could possibly be linked to the protolith or subsequent crustal contamination.

Variation diagrams were plotted to characterize the amphibolites. The relative enhancement in lime and silica concentrations of the amphibolites is portrayed on $\mathrm{SiO}_{2} \mathrm{vs} \mathrm{CaO}$ discriminate plot (Figure 6). Samples from both areas plot within the field of basalts of the Vishu complex (Brown et al., 1979). The tholeiitic chemical character of the amphibolites was revealed on the $\mathrm{Na}_{2} \mathrm{O}+\mathrm{K}_{2} \mathrm{O}$ vs $\mathrm{SiO}_{2}$ discriminant plot (Figure 7). The samples plot within the tholeiitic basalt Field. The $\mathrm{Fe}_{2} \mathrm{O}_{3}-\mathrm{N}_{\mathrm{a}} \mathrm{O}+\mathrm{K}_{2} \mathrm{O}-\mathrm{MgO}$ ternary plot (Figure 8) of Irvine and Barager (1971) showed the tholeiitic affinity of the magmatic precursor of the amphibolites. The tholeiitic affinity of the amphibolites is equally supported by the trend observed on the Ga vs Y bivariate plot (Figure 9), as majority of the samples plot around the 1.0 ratio (Elueze, 1985; Honkamo, 1987).

The $\mathrm{Zr} / \mathrm{Y}$ vs $\mathrm{Zr}$ discrimination diagram (Figure 10) of Pearce et al. (1979) for the amphibolites indicated Mid Oceanic Ridge Basalt (MORB), though with slight overlap in the Island Arc Tholeiitic Basalt (IAT) field. The $\mathrm{TiO}_{2}(<0.9)$ and $\mathrm{P}_{2} \mathrm{O}_{5}(<0.05)$ contents are consistent with the theoleiitic character of the metabasalts (Floyd and Winchester, 1978). The $\mathrm{TiO}_{2}$ and $\mathrm{SiO}_{2}$ discrimination plot (Figure 11) of the amphibolites indicated a negative correlation, which is consistent with an early fractionation of Ti-rich minerals. Also V exhibited a sympathetic relationship with $\mathrm{TiO}_{2}$ (Figure 12). The geochemical association of $\mathrm{Ti}$ and $\mathrm{V}$ in magmatic suites is mainly controlled by the crystallization of ilmenite and titanomagnetite (Graham, 1976). Low $\mathrm{CaO} / \mathrm{Al}_{2} \mathrm{O}_{3}$ ratio $(<0.72)$ for the amphibolites of the study areas suggested igneous ancestry. The strong positive correlation between $\mathrm{Cr}$ and $\mathrm{Ni}$ (Figure 13) also confirms their igneous origin.

Major oxides within the investigated amphibolites showed minor variation in compositions. Major oxides are seldom used, with care, in petrogenetic and geotectonic discriminations. The trace elements, on the other hand, showed wide range in concentrations, and are therefore essentially employed as important petrogenetic discrimination tools (Pearce and Cann, 1973). The trace element compositions of amphibolites from both areas are similar. The Sr (123ppm), Ba (184ppm), Co (71ppm), Cr (79ppm) and Ni (64ppm) contents are slightly higher in Wonu-Apomu samples than the Ilesa samples with 122ppm, 137ppm, 62ppm, 63ppm and 57ppm, correspondingly. The Ilesa samples however showed relative enrichment in $\mathrm{Cu}(61 \mathrm{ppm}), \mathrm{Ga}(36 \mathrm{ppm})$ and $\mathrm{Rb}$ (34ppm). The Ilesa amphibolite samples have $\mathrm{Y}, \mathrm{Zr}$ and $\mathrm{Zn}$ contents of 37, 56 and 83ppm, while the corresponding values for Wonu-Apomu samples are $37 \mathrm{ppm}, 55 \mathrm{ppm}, 96 \mathrm{ppm}$ respectively. The observed trends in 
trace element compositions are so small that significant variation patterns are quite difficult to establish.

Considering the overall trends of the trace element composition, Ba (>137ppm) and Sr 106-145ppm) are comparably lower to other amphibolites elsewhere in Nigeria (Table 3) and fairly exceeded those of the oceanic tholeiites (Clark, 1979). The high Ba value may either reflect plagioclase fractionation, crustal contamination (Olade and Elueze, 1979) or metasomatised source (Stern et al., 1990). Concentration of Co, Cr, Cu, Ga, Ni, V, Y, $\mathrm{Zr}$ and $\mathrm{Zn}$ are observed to be least variable within samples. In comparison to other trace elements, they are relatively immobile during deformation (Floyd and Winchester, 1978), thus showing their significance in petrogenetic and tectonic setting discriminations in altered mafic rocks.

The petrochemical affinity of the amphibolites: $\mathrm{SiO}_{2}(>47.2 \%), \mathrm{Al}_{2} \mathrm{O}_{3}(>15.10 \%)$, and $\mathrm{K}_{2} \mathrm{O}(>0.73 \%)$ compare favourably with that of the Burum amphibolite (Elueze and Okunlola, 2003) and Daldrian metabasalts (Graham, 1976). Other chemical parameters, such as, low $\mathrm{CaO} / \mathrm{Al}_{2} \mathrm{O}_{3}(<0.7 \%)$ and $\mathrm{Rb} / \mathrm{Sr}(<0.30)$ also confirm the igneous origin of the amphibolites. The bivariate plots of $\mathrm{Na}_{2} \mathrm{O}+\mathrm{K}_{2} \mathrm{O}$ vs $\mathrm{SiO}_{2}, \mathrm{Ga}$ vsY, $\mathrm{Zr} / \mathrm{Y}$ vs $\mathrm{Zr}$, with the ternary discrimination diagrams of $\mathrm{Fe}_{2} \mathrm{O}_{3}-\mathrm{Na}_{2} \mathrm{O}+\mathrm{K}_{2} \mathrm{O}-\mathrm{MgO}, \mathrm{TiO}_{2}-\mathrm{K}_{2} \mathrm{O}-\mathrm{P}_{2} \mathrm{O}_{5}$ and $\mathrm{Fe}+\mathrm{Ti}-\mathrm{Al}-\mathrm{Mg}$, all confirmed the tholeiitic basalt precursor for the amphibolites.

Table 3. Average major (wt\%) and trace elements (ppm) composition of Wonu-Apomu and Ilesa amphibolites, compared with other amphibolites elsewhere in Nigeria

\begin{tabular}{lllllllll}
\hline & \multicolumn{2}{c}{ Wonu-Apomu } & \multicolumn{2}{c}{ Ilesa } & 3 & 4 & 5 & 6 \\
& Mean & \multicolumn{1}{c}{ Range } & Mean & \multicolumn{1}{c}{ Range } & Mean & Mean & Mean & Mean \\
\hline $\mathrm{SiO}_{2}$ & 48.91 & $44.78-50.62$ & 47.27 & $44.86-49.10$ & 60.44 & 50.20 & 50.11 & 53.92 \\
$\mathrm{Al}_{2} \mathrm{O}_{3}$ & 15.11 & $14.01-16.41$ & 17.29 & $15.20-20.22$ & 13.76 & 14.37 & 14.75 & 13.21 \\
$\mathrm{Fe}_{2} \mathrm{O}_{3(t)}$ & 13.31 & $12.27-14.62$ & 12.44 & $11.56-13.34$ & 6.54 & 10.83 & 14.75 & 9.06 \\
$\mathrm{MnO}$ & 0.132 & $0.07-0.23$ & 0.11 & $0.08-0.14$ & 0.24 & 0.24 & 0.21 & 0.01 \\
$\mathrm{MgO}$ & 9.84 & $8.08-12.15$ & 9.52 & $7.85-11.16$ & 2.99 & 5.45 & 8.56 & 9.14 \\
$\mathrm{CaO}$ & 9.33 & $8.72-10.00$ & 9.50 & $8.11-10.55$ & 9.24 & 15.26 & 10.34 & 10.78 \\
$\mathrm{Na} \mathrm{O}_{2} \mathrm{O}$ & 1.52 & $1.13-1.88$ & 1.87 & $1.28-2.72$ & 0.01 & 0.19 & 0.63 & 2.0 \\
$\mathrm{~K}_{2} \mathrm{O}$ & 0.73 & $0.46-0.99$ & 0.732 & $0.55-0.85$ & 3.06 & 0.48 & 0.20 & 0.26 \\
$\mathrm{TiO}_{2}$ & 0.048 & $0.25-0.88$ & 0.61 & $0.39-0.86$ & 0.70 & 1.32 & 0.55 & 0.089 \\
$\mathrm{P}_{2} \mathrm{O}_{5}$ & 0.026 & $0.01-0.05$ & 0.03 & $0.02-0.05$ & 0.66 & 0.15 & 0.07 & 1.6 \\
$\mathrm{LOI}$ & 0.308 & $0.25-0.35$ & 1.46 & $0.02-0.05$ & 0.96 & 0.92 & 0.35 & 0.3 \\
\hline $\mathrm{Total}$ & 99.69 & & 99.86 & $0.24-0.35$ & 98.6 & 99.41 & 99.99 & 100.07 \\
\hline $\mathrm{Ba}$ & 184 & $86-350$ & 137 & $88-231$ & 970 & 560 & 520 & 301 \\
$\mathrm{Co}$ & 71 & $40-85$ & 62 & $48-82$ & 17 & 34 & 28 & 149 \\
$\mathrm{Cr}$ & 79 & $58-92$ & 63 & $45-94$ & 130 & 125 & 370 & 117 \\
$\mathrm{Cu}$ & 48 & $35-66$ & 61 & $23-98$ & 315 & 310 & 185 & - \\
$\mathrm{Ga}$ & 27 & $25-29$ & 36 & $23-85$ & 21 & 15 & 22 & - \\
$\mathrm{Ni}$ & 64 & $24-98$ & 57 & $25-85$ & 56 & 81 & 85 & 62 \\
$\mathrm{Rb}$ & 33 & $26-40$ & 34 & $27-46$ & 67 & 5 & 3 & 21 \\
$\mathrm{Sr}$ & 123 & $106-143$ & 122 & $106-145$ & 210 & 260 & 45 & 167 \\
$\mathrm{~V}$ & 71 & $56-94$ & 77 & $56-98$ & 130 & 270 & 133 & - \\
$\mathrm{Y}$ & 37 & $26-45$ & 37 & $25-45$ & 32 & 21 & 17 & 144 \\
$\mathrm{Zr}$ & 55 & $48-62$ & 56 & $46-66$ & 120 & 38 & 5 & 78 \\
$\mathrm{Zn}$ & 96 & $80-120$ & 83 & $62-94$ & 106 & 96 & - & - \\
\hline $\mathrm{Ap}$ & & & & & & & & \\
\hline
\end{tabular}

1: Wonu-Apomu amphibolite

2: Ilesa amphibolite

3: Bako amphibolite (Elueze, 1985)

4: Tegina amphibolite ( Elueze, 1985)

5: Burum amphibolite (Elueze and Okunlola, 2003)

6: Lema-Ndeji amphibolite ( Okunlola et al, 2007) 


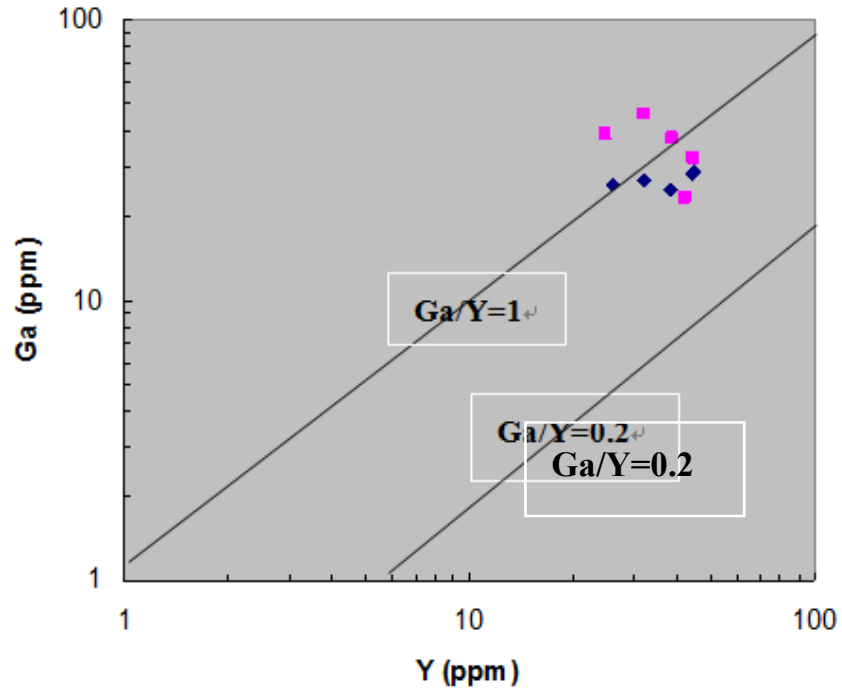

- Wonu-A pomu Amphibolite

- Ilesa Amphibolite

Figure 9. Plot of Ga vs Y for Wonu-Apomu and Ilesa amphibolites

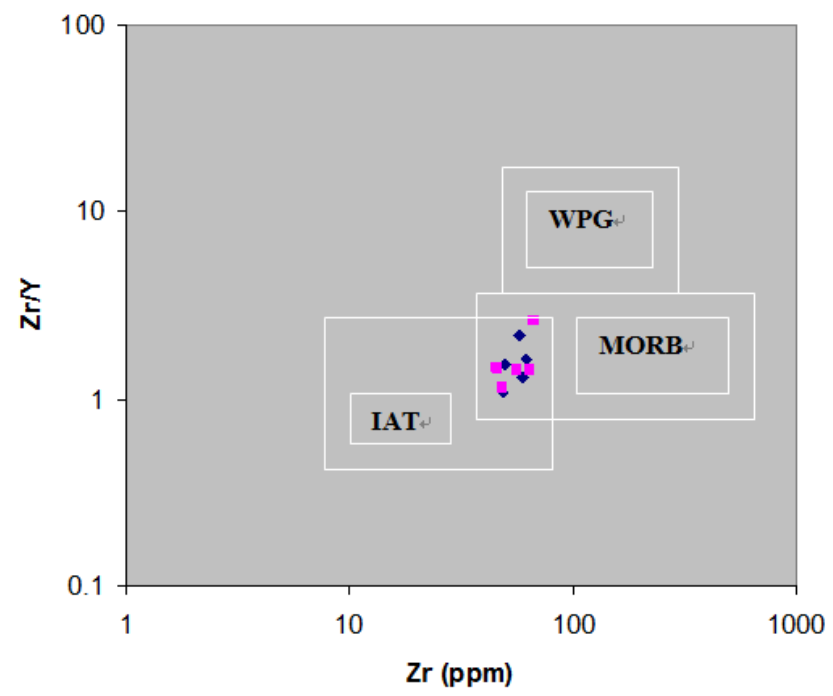

- Wonu-Apomu Amphibolite

- llesa Amphibolite

Figure 10. Plot of Zr/Y vs Zr for Wonu-Apomu and Ilesa amphibolites (Pearce et al., 1979; Pearce, 1980). WPG, within plate granitoids or lava; MORB, mid-ocean ridge basalts; IAT, island arc tholeites

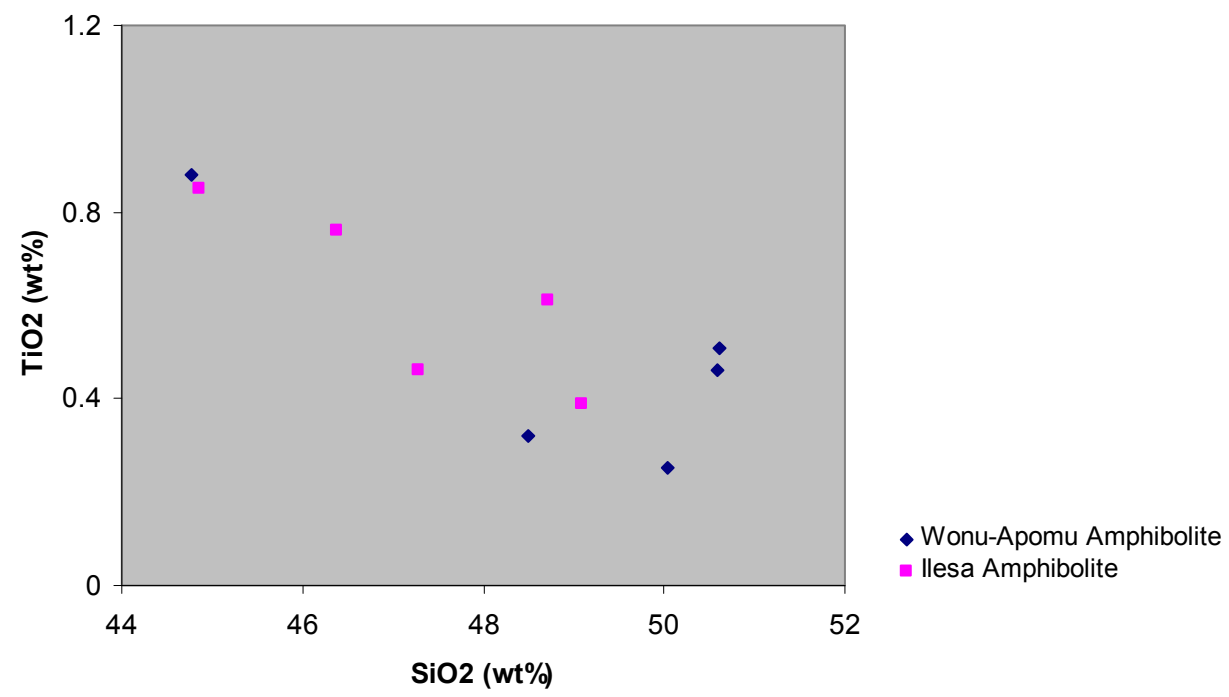

Figure 11. Plot of $\mathrm{TiO}_{2}$ vs $\mathrm{SiO}_{2}$ for Wonu-Apomu and Ilesa amphibolites 


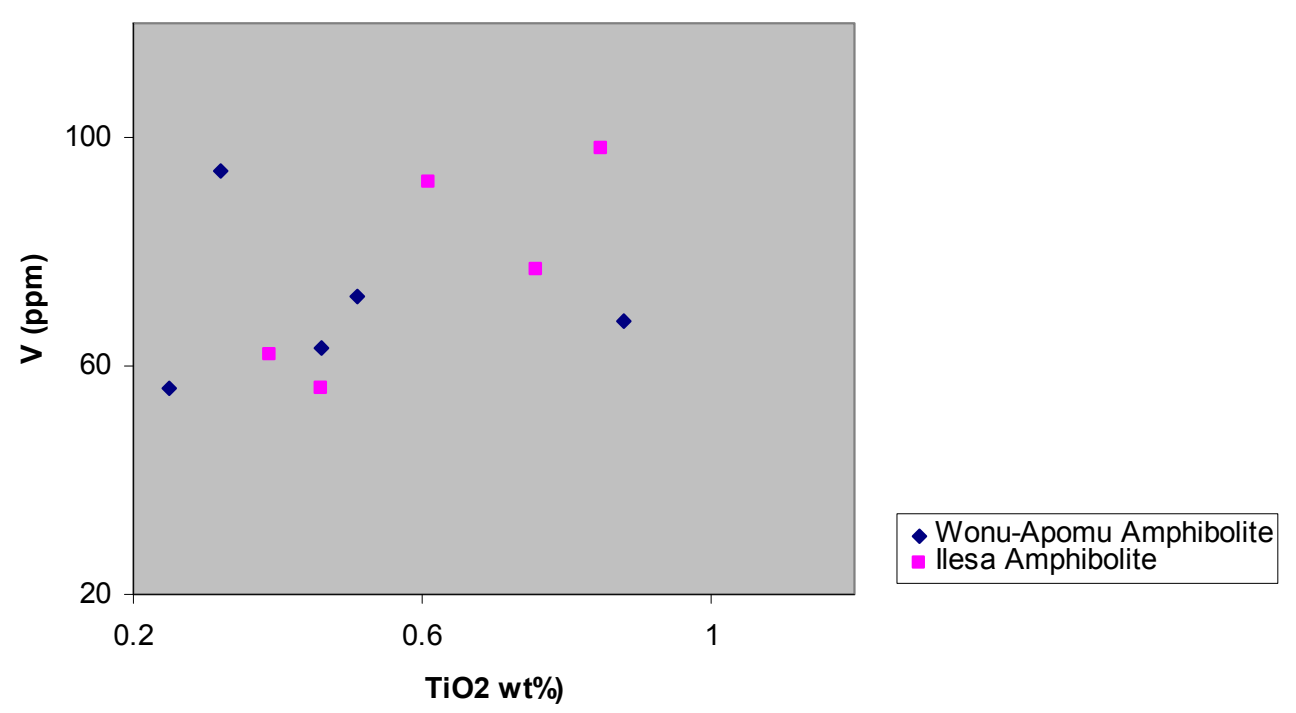

Figure 12. Plot of $\mathrm{V}$ vs $\mathrm{TiO}_{2}$ for Wonu-Apomu and Ilesa amphibolites

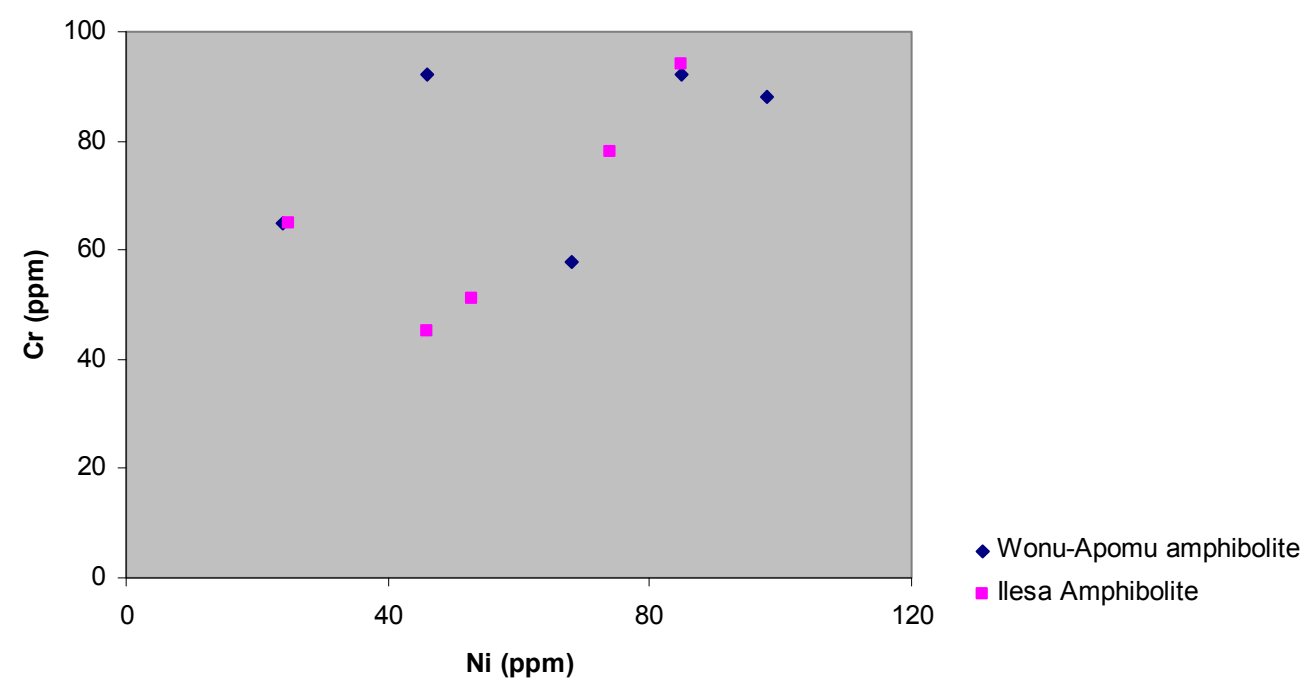

Figure 13. Plot of Cr vs Ni for Wonu-Apomu and Ilesa amphibolites

\section{Conclusions}

Petrographic study of the Wonu-Apomu and Ilesa areas amphibolites showed the dominance of hornblende, plagioclase feldspar, anthophyllite and chlorite. Other minerals present are biotite, quartz, pyroxene and opaques minerals. Chemical data showed subtle resemblance to other amphibolites elsewhere in Nigeria. The tholeiitic nature and the basaltic igneous precursor of the amphibolites were confirmed via the petrochemical indices and discrimination plots.

\section{Acknowledgements}

The authors would like to appreciate Mr. Olawale Aromolaran for his assistance and Mr. Aikhiero Ata for preparing the thin sections. The comments and suggestions of the anonymous reviewers are highly appreciated.

\section{Conflict of Interest}

The authors declare that there is no conflict of interest regarding the publication of this paper.

\section{References}

Adeleye, M. A. (2009). Petrogenetic studies of talc and amphibolites in Wonu-Apomu and Ilesa areas, southwestern Nigeria. Unpublished M.Sc. Project Report, Department of Geology, University of Ibadan, Ibadan, Nigeria. $87 \mathrm{p}$. 
Ajayi, T. R. (1980). On the geochemistry and origin of amphibolites in Ife-Ilesa area, southwestern Nigeria. Journal of Mining and Geology, 17(2), 177 - 196.

Brown, E. H., Babcock, R. S., \& Clark, M. D. (1979). Geology of Precambrian Rocks of Grand Canyon. Precambrian Research, 8, 219 - 241. http://dx.doi.org/10.1016/0301-9268(79)90030-5

Clark, M. D. (1979). Geology of the older Precambrian rocks of the Grand Cayon III: Petrology or mafic schissts and amphibolites. Precambrian Research, 8, 277 - 302. http://dx.doi.org/10.1016/0301-9268(79)90032-9

De Swardt, A. M. J. (1953). The geology of the county around Ilesa. Geological Survey of Nigeria Bulletin 23, $54 \mathrm{p}$.

Elueze, A. A. (1980). Geochemical studies of Proterozoic amphibolites and meta-ultramafites in the Nigerian schist belts: Implications for Precambrian crustal evolution. Unpublished Ph.D. Thesis, University of Ibadan, Ibadan, Nigeria. 288p.

Elueze, A. A. (1982). Metallographic studies of ore-minerals in the amphibolites of Ilesa schist belt, southwestern Nigeria. Journal of Mining and Geology, 18(2), 53 - 58.

Elueze, A. A. (1985). Petrochemical and petrogenetic characteristics of Precambrian amphibolites of the Alawa district, northwest Nigeria. Chemical Geology, $48, \quad 29-41$. http://dx.doi.org/10.1016/0009-2541(85)90033-6

Elueze, A. A. (1986). Petrology and gold mineralization of the amphibolites belt, Ilesa area, southwestern Nigeria. Geol. Mijnbouw 65, 189 - 195.

Elueze, A. A., \& Okunlola, O. A. (2003).Geochemical features and petrogenetic affinity of Precambrian amphibolites of Burum area, central Nigeria. Journal of Mining and Geology, 39( 2), 71 - 78.

Floyd, P. A., \& Winchester, J. A. (1978). Identification and discrimination of altered and metamorphosed volcanic rocks using immobile elements. Chemical Geology, 21(2), 291 - 302. http://dx.doi.org/10.1016/0009-2541(78)90050-5

Graham, C. M. (1976).Petrochemistry and tectonic significance of Daldrian metabasaltic rocks of Scottish High lands. Journal of Geological Society of London, 132, 61 - 84. http://dx.doi.org/10.1144/gsjgs.132.1.0061

Honkamo, M. (1987). Geochemistry and tectonic setting of early Proterozoic volcanic rocks in northern Osthuthoria Finland. In: Pharaoh, T. C., Beckingsale, R. D., \& Richard, D. (Eds): Geochemistry and mineralization of Proterozoic volcanic suites. Geological Society of London Special Publication, 38.

Hubbard, F. H. (1966). A provisional report on the geology of sheet 262 (Apomu) and part of sheet 263 (Ondo). Geological Survey of Nigeria Report 1341.

Hubbard, F. H. (1975). Precambrian crustal development in western Nigeria: indications from Iwo Region. Geological Society of America Bulletin, $86, \quad 548 \quad-\quad 554$. http://dx.doi.org/10.1130/0016-7606(1975)86<548:PCDIWN >2.0.CO;2

Ige, O. A. (1985). Mineralogical and industrial properties of some Wonu Apomu talcs, western Nigeria. Nigerian Journal of Science, 19,121 - 130.

Irvine, T. N., \& Baragar, W. R. A. (1971). A guide to the chemical classification of the common volcanic rocks. Canadian Journal of Earth Sciences, 8, 523 - 548. http://dx.doi.org/10.1139/e71-055

Kehinde-Phillips, O. O. (1991). Compositional variations in lateritic profiles over mafic and ultramafic rock units of Ilesa schist belt, southwestern Nigeria. Unpublished Ph.D. Thesis, University of Ibadan, Ibadan, Nigeria. 201p.

Klemm, D. D., Schneider, W., \& Wagner, B. (1984). The Precambrian meta-volcano - sedimentary sequence east of Ife-Ilesa, southwestern Nigeria.A Nigerian "greenstore belt"? Journal of African Earth Sciences, 2(2), $161-176$.

Okunlola, O. A., Akintola, A. I.,\& Egbeyemi, R. O. (2007). Geological setting, petrochemistry and petrogenetic affinity of Precambrian amphibolites of Lema-Ndeji area, Central Nigeria. Mineral Wealth, 144,47 - 55.

Olade, M. A., \& Elueze, A. A. (1979). Petrochemistry of the Ilesa amphibolites and Precambrian crustal evolution in the Pan-African domain of southwestern Nigeria. Precambrian Research, 8, $303-318$. http://dx.doi.org/10.1016/0301-9268(79)90033-0

Pearce, J. A. (1980). Geochemical evidence for the genesis and eruptive setting of lavas from Tethyan ophiolites, In: Panayiotou, A. (Ed.). Ophiolites. Geological Survey Department, Cyprus, 261-272. 
Pearce, J. A., \& Cann, J. R. (1973). Tectonic setting of basic volcanic rocks determined using trace elements analyses, Earth Planetary Science Letter, 19, 290 - 300. http://dx.doi.org/10.1016/0012-821X(73)90129-5

Pearce, J. A., \& Norry, M. J. (1979). Petrogenetic implication of Ti, Zr, Y and Nb varieties in volcanic rocks. Contributions to Mineralogy and Petrology, 69, 33 - 92. http://dx.doi.org/10.1007/BF00375192

Pearce, T. H., Gorman, B. E., \& Birkett, T. C. (1975). The $\mathrm{TiO}_{2}-\mathrm{K}_{2} \mathrm{O}-\mathrm{P}_{2} \mathrm{O}_{5}$ diagram - a method of discriminating between oceanic and non-oceanic basalts. Earth Planetary Science Letter, 24, 419 - 426. http://dx.doi.org/10.1016/0012-821X(75)90149-1

Stern, C. R., Frey, F. A., Futa, K., Zartman, R. E., Peng, Z., \&Kyser, T. K. (1990). Trace-element and Sr, Nd, Pb, and $\mathrm{O}$ isotopic composition of Pliocene and Quaternary alkali basalts of the Patagonian Plateau lavas of South America.Contributions to Mineralogy and Petrology, 104, 294-308. http://dx.doi.org/10.1007/BF00321486

Turner, D. C. (1989). Upper proterozoic schist belts in the Nigerian sector of the Pan-African Province of West Africa. In: Kogbe, C. A. (Ed.): Geology of Nigeria. Published by Rock View (Nigeria) Limited, p. 96.

\section{Copyrights}

Copyright for this article is retained by the author(s), with first publication rights granted to the journal.

This is an open-access article distributed under the terms and conditions of the Creative Commons Attribution license (http://creativecommons.org/licenses/by/3.0/). 